\title{
How Children in Germany Experience Refugees: A Contribution From Childhood Studies
}

\author{
Sabine Andresen ${ }^{1} \cdot$ Sascha Neumann $^{2}$ (D) . Ulrich Schneekloth ${ }^{3}$
}

Accepted: 5 May 2021 / Published online: 21 June 2021

(c) The Author(s) 2021

\begin{abstract}
This paper deals with perceptions, encounters and experiences of children with refugees and refugee children in Germany. It is based on the Fourth World Vision Children Study, which is regularly conducted in Germany since 2007. The study is based on a representative survey among 6- to 11-year-old children, which was combined with qualitative case studies and focuses on children's well-being, their fears, their concerns as well as their attitudes toward other societal groups and contemporary political issues. For the survey of the Fourth World Vision Children Study, in the questionnaire there were also items included which should allow collecting data on children's encounters and experiences with refugees, and particularly refugees who are their peers. This paper presents the approach taken in the study and how it is embedded conceptually in childhood studies before reporting and discussing selected findings on the experiences of children in Germany with refugees in their neighbourhood and among their peers. The findings presented in this paper refer to contact as well as interactions and opportunities for establishing friendships between refugee and non-refugee children. This is followed by a discussion of the implications these findings have in terms of consequences for supporting refugee children when arriving at Germany. In the conclusion, we will finally point out the implications of our study for the broader field of childhood studies in social sciences.
\end{abstract}

Keywords Children · Refugees · Relationships · Childhood studies · Germany · Survey

Sascha Neumann

sascha.neumann@uni-tuebingen.de

1 Goethe University Frankfurt am Main, Department of Education, Institute of Social Pedagogy and Adult Education, Theodor-W.-Adorno-Platz 6, D-60323 Frankfurt am Main, Germany

2 Eberhard Karls University of Tübingen, Institute of Education, Münzgasse 22-28, D-72070 Tübingen, Germany

3 Kantar Public Germany, Landsberger Straße 284, D-80687 München, Germany 


\section{Introduction: Refugee Children in Germany and the Focus of the Fourth World Vision Children Study}

In 2018 the UNHCR (2019) identified 70.8 million people as displaced and more than two thirds came from five countries: Syrian Arab Republic, Afghanistan, South Sudan, Myanmar and Somalia. Most of refugees stay in neighbouring countries. Nevertheless, 2015 and 2016 showed a relatively short period of a new awareness of this situation also in Germany. More refugees than in the years before crossed the borders and applied for asylum and/or a permanent status. A high percentage were children, who came with their relatives.

In the period from 2015 to mid-2017, approximately 1.35 million refugees arrived in Germany. ${ }^{1}$ The majority came in 2015 with numbers already starting to drop markedly in 2016. Almost a third of the asylum applications in 2015 came from minors. Based on the statistics on asylum applications and the fact that roughly $16 \%$ of registered asylum seekers were identified as being aged 6 to 15 years (school-age children) in 2016 (BAMF, 2017a), this results in about 220,000 refugee children in this age group. By also including children younger than 6 years (roughly a further $14 \%$, ibid.), we can see that a total of up to 400,000 refugee children came to Germany during this period.

When we started to prepare the Fourth World Vision Children Study in 2016 (see World Vision, 2018), not only academics realised the lack of empirical data on refugees and their situation in Germany. In the beginning, knowledge was mainly available about unaccompanied refugees (Gumbrecht, 2018) and about families with a toleration status ('Duldung') in bigger cities like Berlin. Especially for Germany, social reports and such on education did not compile any information until 2016. Also scholars from childhood studies had to realise that they know comparatively little about refugees and their well-being in their countries of arrival (for an overview see Watters, 2014; Sirin, 2018). Most of the research was based on smallscale and regional investigations (see, e.g., Eisenhuth, 2015; Demir \& Ozgul, 2019; Lawrence et al., 2018; Shallow, 2014).

As there was only little knowledge about the situation of refugee families and children in Germany but, at the same time, this was a central socio-political issue in 2015 and 2016 in Germany, we decided to address it by setting a particular focus on this topic in our investigations for the Fourth World Vision Children Study. In Germany, the World Vision Children Study (see World Vision, 2007, $2010,2013,2018$ ) belong to the circle of empirical investigations reporting on the living conditions and well-being of children aged 6 to 11 years at regular intervals. One of the key characteristics of the study is that children are interviewed directly in order to give (indirect) voice to them as experts of their lifeworld as well as of their opinions, feelings and experiences. In doing so, the study locates itself not only in the field of research on children's well-being (cf. Ben-Arieh, 2008) but also in the field of childhood studies, especially in the paradigm of the sometimes

\footnotetext{
1 Our own estimate was based on the statistics on applications for asylum provided by the Office for Migration and Refugees (BAMF) for July 2017 (BAMF, 2017b, 3).
} 
so-called 'new social studies of childhood' (James, 1998). Childhood studies represent an interdisciplinary research space in the social sciences, which emerged on an international level during the first one-third of the twentieth century and became more prominent as a 'new paradigm' of studying children and childhood during the 1980s and 1990s (Prout \& James, 1997; Honig, 2009; Kirchner et al., 2017). A central issue of this 'new paradigm' was to emphasize the role of children as both collective and individual actors in society, which, at the same time, means that children's experiences, needs, concerns and interests were considered as worth to be studied in "their own right" (Hardman, 1973, 87).

Up to now, each World Vision Child Study has focused on a specific key topic inspired by the contemporary socio-political challenges. A major underlying motivation is to find out how children perceive the current topics influencing public discourse. For example, the 2007 Child Study (World Vision, 2007) analysed the situation of 8- to 11-year-old children living in poverty. Its results also triggered a major discussion in the mass media. This led the Second Child Study to examine the experience of poverty in a more differentiated way and make it into a key topic (World Vision, 2010). Since then, the experience of poverty has been surveyed again in each World Vision Child Study and linked to current findings in research on child poverty (Andresen et al., 2017).

The theoretical focus on the concept of child well-being in the 2010 Child Study led to a strong alignment with the Capability Approach (World Visionl, 2010). This discussion then linked up with ideas on a theory of justice in the 2013 Study. This Third Study introduced what was then a novel special focus that has now been extended consistently in the Fourth Study: the children's sense of justice (Andresen \& Schneekloth, 2014). Among others, this examined children's appraisals of what is a just and fair approach to certain social groups such as the aged or the poor in a society, asked them about inequality, and explored their personal experiences with being disadvantaged. Up to this time, there were hardly any studies on this topic apart from Piaget's well-known investigations and more recent experimental research in behavioural economics (Fehr et al., 2008). In the Fourth Study, we have also used some of the questions and case scenarios again. Taking this approach also allows us to illustrate selected trends over time.

The analyses of these findings, and the open questions raised by the first studies have also clearly shown the productive potential of carrying out systematic research on emotions within childhood studies. For example, our own more indepth studies have delivered important findings on aspects such as the feelings of anxiety in children facing poverty and their emotions of security and insecurity (Andresen \& Wilmes, 2016; Frevert, 2013; Magyar-Haas, 2017). This is of importance when we discuss the findings of children's experiences with peers who, as for example refugees, are seeking for help and protection in Germany. The selection of a particular topic for every World Vision Child Study not least goes back to the interest whether and how societal public discourses influence children's views. That is why we decided to focus on children's experiences with refugees and on the perception of the unique situation in Germany in the Fourth World Vision Children Study. 


\section{Research Questions and Methodology of the World Fourth World Vision Study}

\subsection{Focus and Research Questions}

The situation in Germany in 2015 and 2016 not only led to vital public discourses and controversial political debates. Most interesting, however, was the fact, that we became aware of many pedagogical activities aimed at integrating refugee children as quickly as possible in the educational system, and we saw both professional and voluntary activities. These observations gave cause for first general questions with regard to the views and experiences of children: How do children perceive the 'refugee' phenomenon, how do children look at the supporting events organised by the citizens, how do they appraise meetings and experiences with refugee children, how do they evaluate their encounters and relations in terms of justice, humanity and their everyday experiences?

Even though the images of refugees shown in the media did create a different impression, the proportion of people and children with refugee background in Germany is comparatively small. Refugee children who came to Germany from 2015 to mid-2017 make up approximately three percent of the country's child population. In comparison, there were approximately 7.35 million children aged 6 to 15 years living in Germany in year 2015 and approximately 11.7 million children under the age of 16 (Genesis Online, as on 31.12.2015). Hence, for the World Vision Children Study to be started in 2016 we could not expect a significant number of children with refugee background participating in our representative survey. This was the reason, why we decided to contribute to further knowledge on the situation of refugee children not by addressing their situation and themselves directly in our survey but by asking how children already living in Germany before 2016 perceive the situation of refugees and what we can find out about their experiences with refugee children.

By doing this, we also wanted to get an impression of the perceptions and experiences of the German society as a whole in relation to the causes for and movements of refugees and the challenges they create, and we wanted to explore this on the ground level: that is, in the communities, the children's day care centres, or schools (Andresen \& Neumann, 2018, 49-50). Hence, the study did not address the life situation of refugee children themselves directly, but the experiences that children already living in this country have in their everyday dealings with refugees. However, we picked up the situation of being a child with a refugee background in a special section of both our standardized interviews in the survey and our qualitative interviews in terms of the social contacts and the quality relations non-refugee children reported. To assess children's experiences with the refugee phenomenon, we linked it - as in the study as a whole - to the daily activities of children and the central locations in which they live (family environment/residential area, school/leisure time). Our focus was on everyday meetings between children and families living in Germany and children and families seeking protection here. We wanted to know whether children have such meetings 
with refugees, where they meet them, and how frequently they meet them. We linked this to the experiences articulated by children: How do they experience these events? Do meetings lead to stable relationships and perhaps even friendships? How do they in any way communicate with each other? Moreover, we also wanted to know in which ways children themselves are involved in providing help and support to refugees. Finally, we wanted to know what they think about such events and experiences. How do children see refugees, above all, also in light of the challenges their presence raises, the problems they have with them, or whether they are being treated fairly and justly in school and classroom lessons?

The special focus on the immediate settings of the children can be linked to what Bronfenbrenner called 'microsystems' in his ecological systems theory (Bronfenbrenner, 1989) and, thus, falls into line with a theoretical lense widely used in the field of research on children's well-being when it comes to the question how to distinguish contextual, extra-personal factors and influences from individual ones (cf. Newland et al., 2015; Thommessen \& Todd, 2018; UNICEF, 2020). Combined with the focus on experiences and reactions of non-refugee children this leads to an approach which also allows to identify in how far the conditions on the level of the 'macrosystem' (e.g. political decisions, societal norms) and the 'microsystem' (e.g. institutions such as schools) are reflected in the everyday contacts and relations of refugee and non-refugee children. In regard to the micro level of everyday life, we were primarily following the hypothesis that the chance to meet refugee children in the neighbourhood, at school or other care settings on a daily routine would have a positive impact on the number and the quality of relationships between children without and with refugee background which, then, probably also would contribute to refugee children's mental health and well-being (Luthar, 2015). Research from childhood studies on how children make friends clearly demonstrates the importance of (continuous) opportunities to meet, interactions and doing things/playing together for the development of stronger ties, such as friendship, and that especially schools play a crucial role in this context (cf. Corsaro et al., 2003; Danby et al., 2012). In addition, there are multiple studies highlighting that friendships and relations to peers are valuable sources of social support and indispensable conditions for refugee children's psychological and sociocultural adaptation (cf. Berry et al., 2006; Thomessen \& Todd, 2018). In the following chapter on the findings of our study, we concentrate on the opportunities for making contact available to children with and without refugee experience.

\subsection{Methodology}

Although the history of childhood studies reveals a series of controversies over the role of the child in the research process, one major aim right from the start of the World Vision Child Studies has been to accentuate children's perspectives in a systematic way and granting them an epistemological value (see Prout \& James, 1997; Honig et al., 1999; James, 2007). Following such an approach, also the Fourth World Vision Child Study applied a methodological framework and practical research tools to get 
access to the perspectives of 6- to 11-year-old children. Hence, in the mixed-method design of the study, the perspectives of children gain significance in two ways. On the one hand, the children act as the main informants in the quantitative and qualitative data collection. On the other hand, it is the children's viewpoints, concerns and experiences, which are at the centre of our analysis.

For more than 10 years, the World Vision Child Study team has been gathering experience with both quantitative and qualitative survey instruments. This experience has always been guided by feedback from the children in the process of developing the questionnaire and the interview guideline. This practice is not perfect and it has its own limitations for focussing on children's participation in the research process. This is especially the case beyond the data collection: We did not involve children in the analyses of the data, in scientific publications and reports to the public.

Hence, it would be misleading to claim that we let the children talk to us and the public in all phases of the research process. At the same time, it would be not appropriate to claim that we can represent their perspective one to one. In this paper, it is far more the case that we talk about what we have found out and hope that our findings are also in the interest of the children. Ethically, this speaking for others adopts the premise that both the way we are talking and the accompanying intentions or demands are acceptable to the children both at the present time and later (Brumlik, 1992).

Such a practice may well reveal signs of taking more of a traditional approach than a progressive and more radical child-centred or participatory research strategy (cf. Gallacher \& Gallagher, 2008). In the World Vision Child Studies, children are not integrated into the entire research process as equal partners in line with the principle demands of participatory research with children (Groundwater-Smith et al., 2015). Indeed, the experiences we gain through our studies may well also be used to develop participative approaches. At the same time, they plot out the possibilities and the ethical as well as epistemological limitations of a research on children that addresses them as the experts on their own life worlds.

The data we are referring to in the following were collected in 2017 by means of a standardized Computer Assisted Personal Interviews (CAPI). For the interviews $n=2.550$ children were selected on the basis of a quota sample, recruited from a professional and well trained staff of 374 Interviewers from Kantar Germany. The interviewers located in different communities and regions all over Germany recruited the children themselves via private and/or organizational networks and other personal contacts. During the recruitment the sample was weighted by age and gender, type of school (elementary school or secondary school as "Hauptschule", "Realschule", "Gymnasium", "Förder-/Sonderschule"), migration background and German citizenship, federal state ("Bundesland") and the type of settlement structure (urban agglomerations with high or low density, urbanized areas with high density or with and without regional centres, rural spaces with higher or lower density). As the living conditions in the western part of Germany (including Berlin) and the so-called new Federal States ('neue Bundesländer') in the eastern part of Germany are still significantly different we were also applying a disproportional sampling strategy. According to the different size of population in both areas of Germany we included more children from the western part of the country $(n=1.811)$ than of the eastern part $(n=739)$. This provided us with a reasonable 
statistical basis for various comparisons between these two areas. In order to balance the sample, we used available national demographic data as the current population statistics and special analyses of the latest German micro census (see, e.g., Statistisches Bundesamt (Destatis), 2017a, b). As a result of our selection strategy and weighting procedure the sample is proportional to the population of schoolchildren in Germany aged between 6 and 11 years. $^{2}$

In addition to the standardized Computer Assisted Personal Interviews (CAPI), we also conducted 12 qualitative interviews with 8 to 9-year-old children. In these interviews we were focusing on the social networks of children, their everyday experiences as well as their subjective well-being in the contexts relevant to them (school, family, relationships etc.). Moreover, we also asked these children about their perspective on refugees in Germany, how they think about the situation and the needs of refugees and what they think about how society deals with these people. The children for the qualitative interviews were selected from private networks against the background of the different living conditions of children in Germany. Hence, we included boys and girls from the western and the eastern part of Germany with different socioeconomic backgrounds and living in different family settings (e.g. single parent families, with or without siblings etc.). We also paid attention to select children from families with migration background and from rural areas of the country. Based on these qualitative interviews, we prepared 12 portraits of the different children, which served as an important source for interpreting and further illustrating the quantitative data from the survey.

\section{Empirical Findings: Children in Germany and Their Experiences With Refugee Children}

\subsection{Opportunities for Contact Where Children Live}

In the part of our survey referring to the experiences with refugee children, we first asked whether refugees had been housed in the district and then whether they had been housed in the child's (if necessary, extended) own residential area (Fig. 1). A pre-test carried out before revealed that the children in our age group were highly familiar with the terms 'fleeing' and 'refugees' and the same was experienced in the 12 qualitative interviews. The children in the pre-test fully understood our introductory paragraph: 'During the last two years, many people have left their homes and fled here to Germany in search of safety. This is something there has been a lot of talk about here in Germany'. Moreover, they were also able to say things about the topic themselves.

Altogether, nearly every second child (45\%) reports that refugees are being housed in or had moved to their residential area. This rate is comparatively high

\footnotetext{
${ }^{2}$ Quota sampling is a type of non-probability sampling. If the strategy can rely on a large number of interviewers, it is very effective in drawing samples with more difficult-to-recruit members who may not belong to similar social networks.
} 


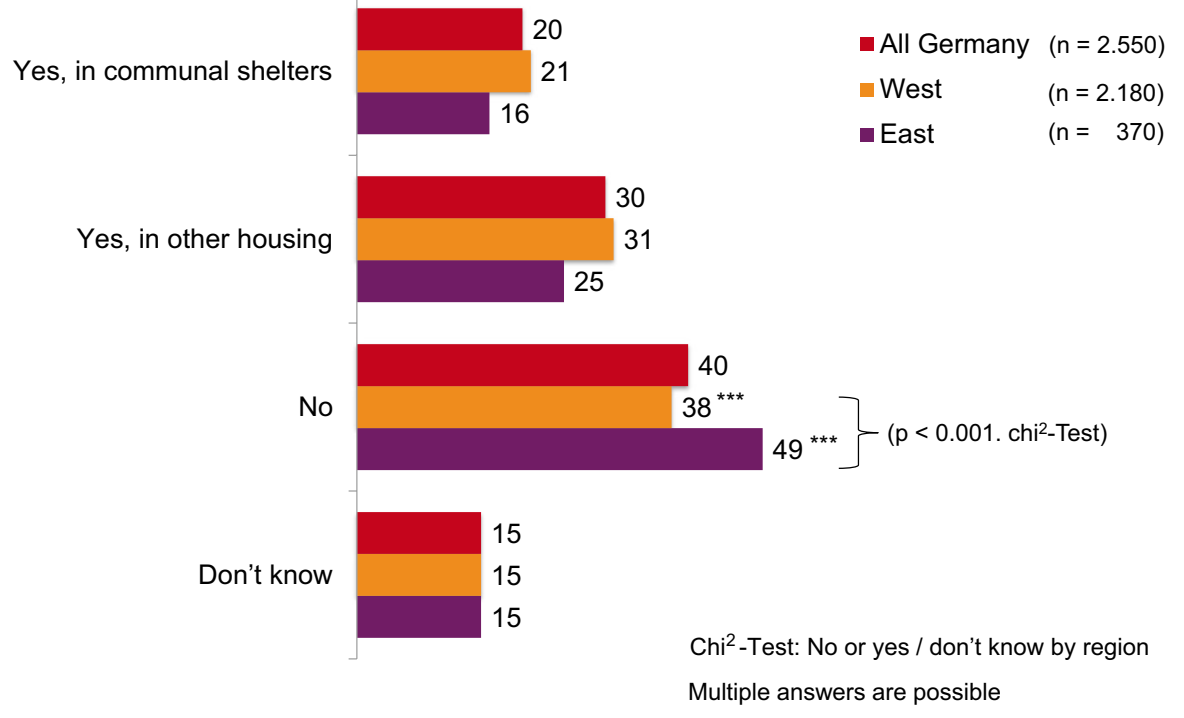

Fig. 1 Refugees in the children's residential area (Schneekloth et al., 2018, 201)

when it is considered that refugees themselves make up only less than two percent of the total population in Germany. Twenty percent of the children surveyed mention communal shelters and a further 30\% mention other housing in which refugees are living (multiple answers possible). About $15 \%$ are not certain and give no answer, whereas 40\% simply answer 'no' (Fig. 1). In a comparison of West and East Germany, markedly more children in the West report on refugees being housed in their neighbourhood than in the East (Old Federal States including Berlin: 47\%; New Federal States: 36\%: highly significant: $\mathrm{p}<0.001$ ).

The children's reports seem plausible. The national distribution of refugees is set by quotas using what is known as the 'Königstein' formula that is based mostly on the tax revenue of each Federal State. This results in a relatively larger number of refugees being housed in the old Federal States; that is, in the West. The reference to 'other housing' is also decisive. Particularly those who have been granted asylum tend to leave communal shelters and either live in a home on their own or move in with friends or relatives. Naturally, we cannot rule out the possibility that misunderstandings emerge here - and not just among children - with refugees being confused with migrants who have come to Germany for other reasons and perhaps even a long time ago. ${ }^{3}$ This was also an insight gained by the analysis of the qualitative interviews: A small group of children struggles to distinguish refugees from people with migration background in general or uses

\footnotetext{
3 In the preceded pre-test-study we used a cognitive testing strategy to find out what children know about refugees (knowledge and imaginations). The key finding was, that children of this age group (6 to 11 ) in Germany could describe refugees in a very appropriate way.
} 
idiosyncratic classifications such as 'a real refugee' or a 'no-longer-real refugee' (Andresen et al., 2018, 252).

There are no significant 'urban versus rural' differences (communal shelters are mentioned somewhat more frequently in urban areas and city districts, whereas other housing is mentioned more frequently in peripheral or rural areas). What is interesting is that children with concrete experience of poverty (60\%), children with a migration background (51\%) and children without German citizenship (61\%) far more frequently report that refugees are living in their own residential area or city district (Table 1).

Such answers from these groups of children may well indicate more sensitive perceptions. Nonetheless, the higher proportion of children with concrete experience of poverty saying refugees have moved into their residential area demonstrates that refugees actually do live in these city districts more frequently - not only in communal shelters but also and particularly in other housing. Hence, there is a greater probability that children with concrete experience of poverty or a migration background will have contact with refugee children and families in their own residential area. It can be assumed that socio-spatial segregation effects play an important role here: Refugees evidently tend to be housed in areas in which families and children with their own migration background or rather low socio-economic status live. This kind of segregation is widely acknowledged in research on the influence of neighbourhoods on social relations of young and adult immigrants, although it should be kept in mind that the neighbourhood effect not least is also moderated by the socioeconomic status of the people with migration background (cf. for Germany; Kruse, 2017).

\subsection{Opportunities for Contact in Daily Life}

When we have asked children whether they have ever met refugees (children or also adults) and where they have met them and, accordingly, have gained more concrete experiences with them (Fig. 2), the most typical location reported is the school

Table 1 Children with refugees in the neighbourhood, distribution by own concrete experience of poverty or migration background (Schneekloth et al., 2018, 202) Basis: children aged 6 to 11 years

\begin{tabular}{llllll}
\hline & Total & $\begin{array}{l}\text { With no experi- } \\
\text { ence of poverty }\end{array}$ & $\begin{array}{l}\text { With experi- } \\
\text { ence of } \\
\text { poverty }\end{array}$ & $\begin{array}{l}\text { Without migra- } \\
\text { tion background }\end{array}$ & $\begin{array}{l}\text { With migra- } \\
\text { tion back- } \\
\text { ground }\end{array}$ \\
\hline Total abs & 2.550 & 2.070 & 480 & 1.634 & 916 \\
Columns in $\%$ & & & & 18 & 24 \\
Yes, in communal shelters & 20 & 19 & 24 & 28 & 33 \\
Yes, in other housing & 30 & 27 & 43 & 42 & 51 \\
Total yes & 45 & 41 & 60 & $42^{* *}$ & $36^{* *}$ \\
No & 40 & $43^{* * *}$ & $27^{* * *}$ & 16 & 13 \\
Don't know & 15 & 16 & 13 & & 16 \\
\hline
\end{tabular}

$* * 0,001 \leq \mathrm{p}<0,01$. Chi2-Test: No or total yes / don't know by migration background

$* * * s p<0.001$. Chi2-Test: No or total yes / don't know by experience of poverty 
(school playground, school premises: 63\%; own class: 41\%). Education is compulsory for all children in Germany including refugees, although actual practices can vary somewhat between Federal States. Basically, refugee children are enrolled in school when they leave the initial registration facilities for asylum seekers and refugees (i.e. after 3 to 6 months), even when there is still no decision on their residential status. School enrolment, especially in primary schools, is generally integrative or semi-integrative and flanked by either special German language classes or, at times, preparatory or welcoming classes (Maaz \& Jäger-Bieler, 2016). Hence, non-refugee children and refugee children are brought together institutionally in the school and especially in primary school.

Forty-two percent of children report on opportunities for contact in the playground or at a youth club or similar institutions for young people. Twenty-two percent report a day-care centre; and a further $15 \%$, a club or organized group to which they belong. The latter rate seems rather low. Even when based only on those children who belong to a club or an organized group (74\%), this means that only $20 \%$ of children in clubs or other organized groups come into contact with refugees. Finally, seven percent report contacts in the family. If we sum up all these opportunities for contact in which children can predominantly meet refugee children, we find that a total of $74 \%$ of children name one or more of these areas.

Further relevant opportunities for children to come into contact with refugees and also particularly adult refugees are typical everyday meeting places: $58 \%$ report having met refugees now and then 'when going shopping' and a further $57 \%$ 'in the city, on the bus (or similar)'. Twenty-seven percent indicate quite generally 'in the neighbourhood where I live', and a further 33\% say 'somewhere else'. 'None of these', that is, not yet having ever met a refugee, is named by no more than $13 \%$

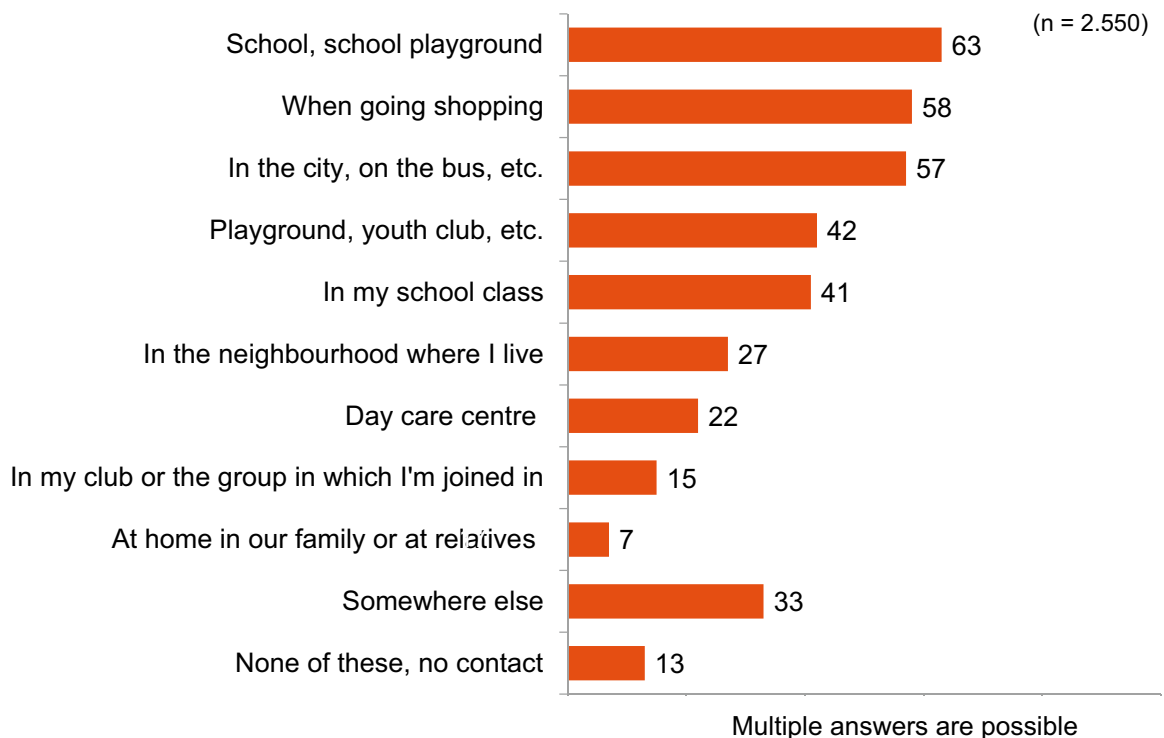

Fig. 2 Opportunities for contact with refugees in daily life (Schneekloth et al., 2018, 203) 
of children. The study asked about a wide range of contact areas in order to avoid imposing any advance limits on the different opportunities for children to gain their own impression of refugees. Hence, this item should not be confused with the previously presented item asking whether refugees have been housed in the immediate residential area.

There are no relevant differences between children in the eastern versus the western part of Germany. The same applies for urban versus rural areas. Younger children aged 6 to 7 years somewhat more frequently report not having met any refugees up to now (20\% compared to about $10 \%$ in children aged eight to 10 or 11 years), and the latter is also the case for all contact areas surveyed. Nonetheless, the majority of younger children are aware of the presence of refugees in their daily lives and can report on them.

In summary, refugees are present in the daily lives of children in Germany. This results in (various) opportunities for contact, and thus for concrete experiences of refugees in everyday life. An important area for making contacts with refugee children is the school. This is not just named most frequently. School also offers the opportunity to relate to each other in a shared context and thereby get to know each other better. Further possibilities for contact are the residential area, for example, in playgrounds or anywhere else that children spend their time and daily lives.

\subsection{Interactions and Relationships With Refugee Children in Daily Life}

The findings on opportunities for contact in daily live do not yet tell us much about their quality but these opportunities form an important basis for encounters which can result in positive engagements with the other and can contribute to a sense of belonging and involvement for both refugee and non-refugee children across difference. Anti-essentialist research on cultural identities, everyday practised multiculturalism and transnationality has shown that such encounters become fruitful, when they are linked to personal experiences of acknowledgement as a both integral and different part in various contexts (Colombo, 2010; see also Hall, 1990). Research in childhood studies focusing on the position and experiences of children from the perspective of transnational migration studies is as well emphasizing the importance of this issue when children with so-called 'multiple belongings' are striving for agency in local contexts of everyday life (see Fattore, 2016; Kämpfe \& Westphal, 2016). Hence, it is also necessary to pay attention to interactions between non-refugee and refugee children and to the conditions making it likely that contacts may result into closer or even friendly relationships. Looking at the results of our study from the perspective of how far contacts with refugee children also lead to interactions with them reveals further interesting patterns. Such interactions are to be found in daily life and they are widespread. This is shown by the children's answers to the question whether they 'now and then do something together with refugee children' in their daily lives. Almost one-third (30\%) answered 'yes'; 55\% said 'no'. The remaining children either had no opportunities for contact (13\%) or were unable to answer the question ('Don't know' or 'No report': two percent) (Table 2).

The roughly $30 \%$ of children who say 'yes' seems to be a relatively high proportion when it is considered that refugee children make up no more than three percent 
Table 2 Doing something together with refugee children by age group and gender (Schneekloth et al., 2018, 205). Basis: Children aged 6 to 11 years

\begin{tabular}{lllllll}
\hline & Total & Girls & Boys & $6-7$ years & $8-9$ years & 10-11 years \\
\hline Total abs & 2.550 & 1.239 & 1.311 & 746 & 894 & 911 \\
Columns in \% & & & & & & \\
Yes, I do & 30 & $28^{*}$ & $32 *$ & $25 *$ & 33 & 31 \\
No, I don't & 55 & 58 & 53 & 52 & 55 & 59 \\
$\begin{array}{l}\text { Have not met any } \\
\text { refugees yet }\end{array}$ & 13 & 12 & 14 & 20 & 11 & 9 \\
\begin{tabular}{l} 
No report \\
\hline
\end{tabular} & 2 & 2 & 1 & 3 & 1 & 1 \\
\hline
\end{tabular}

Age-Group: linear by linear not significant

$* 0,01 \leq \mathrm{p}<0,05$. $\mathrm{Chi}^{2}$-Test: Yes, I do or No, I don't / not met any refugees / no report by migration background or by Age-Group

of all children in Germany. However, there are also marked differences between the various groups of children in the survey's sample. This applies, for example, to boys who, compared to girls (32\% vs $28 \%$ ), more often state that they are doing something together with refugee children. We found a similar difference in relation to age groups: Here, it is the younger children between six and seven years who report less frequently that they are doing something with refugee children. Apparently in line with this, younger children also state more often that they do not have met any refugees yet (20\%). Other differences appear when comparing children with versus without concrete experience of poverty, children with versus without a migration background, or children with versus without German citizenship (Table 3).

The table shows that $35 \%$ of children with a migration background and even $53 \%$ of children without German citizenship report now and then doing something together with refugee children (highly significant: $\mathrm{p}<0.001$ ). Results are similar for children with experience of poverty at $39 \%$ (highly significant: $p<0.001$ ). This corresponds, in turn, with another finding from our study: at 38\%, it is also children with the lowest socio-economic status who frequently report doing 'now and then' something together with refugee children. ${ }^{4}$ The main explanation for this is that the proportion of children with a migration background and of children with experience of poverty is significantly higher in this social class.

The groups examined more closely here are also those reporting more contacts with refugees in the areas in which they live (see Table 1). This is a clear indication that having opportunities for contact within the social surroundings increases the probability of meetings, interaction, and relationships. Such a link is correspondingly also reflected

\footnotetext{
${ }^{4}$ In order to determine the socio-economic background of children, we constructed an index of social status based on data collected with a questionnaire for the parents. The assignment of social status was done by calculating a summated score including information about the educational background of parents, the number of books at home, the type of housing and the sufficiency of the families' income per month (see Pupeter et al., 2018, 352). The summated scores were used to distinguish five social classes: underclass, lower middleclass, middle class, upper middle class, and upper class.
} 
Table 3 Doing something together with refugee children by experience of poverty and migration background (Schneekloth et al., 2018, 207). Basis: Children aged 6 to 11 years

\begin{tabular}{|c|c|c|c|c|c|c|}
\hline \multirow[t]{2}{*}{ Columns in $\%$} & \multirow[t]{2}{*}{ Total } & \multirow[t]{2}{*}{$\begin{array}{l}\text { Without experi- } \\
\text { ence of poverty }\end{array}$} & \multirow{2}{*}{$\begin{array}{l}\text { With experi- } \\
\text { ence of } \\
\text { poverty }\end{array}$} & \multirow[t]{2}{*}{$\begin{array}{l}\text { Without migra- } \\
\text { tion background }\end{array}$} & \multicolumn{2}{|c|}{$\begin{array}{l}\text { With migration back- } \\
\text { ground }\end{array}$} \\
\hline & & & & & Total & $\begin{array}{l}\text { Non- } \\
\text { German } \\
\text { nationality }\end{array}$ \\
\hline Total abs & 2.550 & 2.070 & 480 & 1.634 & 916 & 199 \\
\hline \multicolumn{7}{|l|}{ Columns in \% } \\
\hline Yes, I do & 30 & $28 * * *$ & $39 * * *$ & $27 * * *$ & $35 * * *$ & $53 * * *$ \\
\hline No, I don’t & 55 & 56 & 53 & 57 & 52 & 41 \\
\hline $\begin{array}{l}\text { Have not met } \\
\text { any refugees } \\
\text { yet }\end{array}$ & 13 & 14 & 7 & 14 & 11 & 6 \\
\hline No report & 2 & 2 & 1 & 2 & 2 & - \\
\hline
\end{tabular}

Without migration background, migration background with German nationality and without German nationality: linear by linear also highly significant $(\mathrm{p}<0.001)$

$* * * \mathrm{p}<0.001$. $\mathrm{Chi}^{2}$-Test: Yes, I do or No, I don't / not met any refugees / no report by experience of poverty or by migration background/without German nationality

in other of our findings (see Schneekloth et al., 2018, 212-213): For example, every second child who reports refugees living in housing in their residential area says that they do something with them (now and then do something with refugees: 18\%; refugees belong to my circle of friends: $32 \%$ ). If they report about communal shelters in their residential area, then this still applies for $36 \%$ (now and then do something with refugees: $13 \%$; refugees belong to my circle of friends: $23 \%$ ). If, in contrast, no refugees live in the child's residential area, only $19 \%$ say that they do something with them (now and then do something with refugee children: seven percent, refugees belong to my circle of friends: $12 \%$ ). Hence, the type and intensity of contact between non-refugee and refugee children is shaped primarily by opportunities. Where opportunities for contact are given and where they lead to interactions, refugee children - despite their frequently precarious situation and the given language barriers - are also integrated into the social networks of non-refugee children. These findings represent a strong argument in favour of making sure that access to everyday opportunities for contact and meetings with people already living in Germany should be made available as rapidly and comprehensively as possible for refugee children.

\section{Discussion}

In summary, our study shows that children are highly familiar with the topic of 'refugees' as well as the public discourse over them, and they also have experiences with refugees that they are able to articulate. At the same time, it reveals that children make an important contribution to helping these people to become members of 
our society through their contacts and relationships. If children have opportunities to make contact with refugees and develop peer relationships with them, they use these opportunities to exchange experiences, engage in common activities and to support each other. Against this background, the results of our qualitative study show that children require a diversity of opportunities to get in contact, built social networks and finally make friends. This assigns a key role to schools and child and youth welfare facilities on the community level, because these are the places in which contacts and meetings become possible and probable. Against the background of the experiences children report themselves, it is highly recommended that refugee children should be enrolled in existing educational institutions and families should be housed appropriately and humanely in municipalities and city districts. Integration will commence only when refugee children do not stay too long in reception centres but are quickly assigned to municipalities.

However, the experiences with refugees are not the same for all children. It is far more the case that differences systematically follow significant demarcation lines. Particularly striking is that it is above all children with a migration background who far more frequently report contacts, interactions, and friendships than children without a migration background. There may be different reasons for this: It may be due to living in the same areas, better possibilities of understanding each other's language, or a sense of social closeness due to shared experiences of migration and belonging to a minority as it has been demonstrated in other studies (cf. Bergnehr et al., 2020; Maegusuku-Hewett et al., 2007). Regardless of the possible reasons, this finding is nonetheless particularly informative, because it indicates that children with a migration background are evidently important gatekeepers who provide refugee children with access to social networks.

Our results reveal as well that providing opportunities to meet and interact on an informal and everyday level still seems to be a major challenge for policymakers dealing with people seeking protection in Germany. However, this is not only a question of transfers, services and infrastructures offered by the welfare state and its institutions. It also depends on the opportunity for encounters between refugee and non-refugee children on the local level of everyday life. These opportunities are not reflected in the criteria of the 'Königstein' formula, on which the distribution of arriving refugees to the single federal states in Germany is currently based on, because the 'Königstein' formula just relates to tax revenues and population size. Moreover, the distribution on the federal level is accompanied by arbitrary decisions in the Federal States on the localities of central accommodations for the initial registration of refugees or, in case of an (early) distribution to communities, this is again mostly based on the local population size and/or the economic force of municipalities. After granting of asylum, it is mandatory for recognised refugees to stay for three years in the federal state where they have applied for asylum first (unless they have an employment subject to social insurance contributions, their nuclear family lives elsewhere etc.). This is the case since 2016 and means, that the federal rules for the initial distribution of refugees play also an important role for the first years after their arrival. Empirical data on the movements of recognized refugees shows that they by far more frequently live in cities or even bigger cities with more than 100.000 inhabitants (Rösch et al., 2020). Further interpretations of these 
data suggest, that recognised refugees prefer municipalities that have strong migrant communities from their home countries with the corresponding cultural institutions (Geis \& Orth, 2016). Leastwise, it is not in contradiction to our finding that it is especially the children with migration background who report far more often about contacts and interactions with refugee children. However, in relation to the criteria for distributing refugees and their families it is quite obvious that, in terms of supporting refugee children by offering them opportunities for daily encounters with non-refugee children, there is still a lack of defining and applying appropriate indicators. Such indicators for the initial settlement of refugee children should not only take into account the economic wealth, the population size of municipalities or employment opportunities for adults, but also the availability of adequate housing for families, the accessibility of social and cultural support services as well as of early childhood education institutions and schools.

\section{Conclusions for Further Research Beyond and Within Childhood Studies}

The streams of refugees in the past years and their individual, social and political consequences imposes new challenges on the institutions in the country of arrival. However, it is not only the institutions and those working in them but also children without a refugee background who are at times confronted with new experiences resulting from this situation. Up to now, in Germany and elsewhere there has been little sound knowledge on how the education system and the institutes and bodies responsible for child and youth services have worked and continue to work with refugee families and children (see, for Germany et al., 2014; Hartwig et al., 2018). Inspecting the relevant literature and research reveals that it also has been missed to document and process valuable experiences in dealing with refugees from the war in Yugoslavia (Andresen \& Gerarts, 2016). This was not just the first military war within Europe since World War 2. It also replaced the classic war between states with purportedly ethnically and religiously motivated violence within states (Calic, 2005). The subsequent increase in wars within rather than between states and the ensuing large-scale 'refugee crises' to which this has led represent a major challenge for social work with refugees and indicate a need to restructure not only social work but also child and youth welfare services in both Germany and Europe as a whole. It becomes abundantly clear how important it is to grant refugee children access to education and care institutions as quickly as possible (Riedel \& Lüders, 2016).

Since we conducted the survey, a growing number of studies shows the interest in refugee children, the situation of families, aspects of integration, support, protection and education. During the last years, empirical research on the national and international level has addressed the situation of refugee children and families in diverse ways and from different disciplinary perspectives. This also applies to major reviews on the state of the art of research and comparative studies providing a broader picture on the situation of refugee children. As these major reviews and comparative studies show, research is not only focussing on issues of education and integration, but also on other aspects relevant to the well-being of refugee children like general 
living conditions, socioeconomic status, particular needs, mental health issues or the provision of support by welfare services, schools or early childhood education (see for example Dryden-Peterson, 2016; Nakeyar et al., 2017; de Wal Pastoor, 2016; Sullivan \& Simonson, 2016; Tobin, 2019).

For Germany, we can identify several key topics in the field of research on the situation of refugee children and this could offer a heuristic framework for further research about the quality of relationships between children with and without a refugee background. One key topic is the research about trauma, therapy, the situation of traumatised children, and resilience (e.g. Fingerle \& Wink, 2020; Wünsche \& Fischer, 2020). Another strand of research is about refugee children in the education system (e.g. Bartz, 2018; Ismail, 2018; Meiner-Teubner, 2016). A third one focuses on the situation of families, child protection, families and youth services and parents' integration in the labour market (e.g. Hartwig et al., 2018).

On the basis of our findings from 2018 we can argue, that the quality of integration in the peer group of other children depends strongly on how far they are able to develop viable social relationships. Although this is primarily of interest to integration policy, the findings are also significant in a narrower sense for childhood studies in the social sciences. They highlight the lifeworld experiences children have with refugees and show whether or how they make contact with children seeking protection and in which ways and how intensively the refugee phenomenon confronts children in their daily lives. In consequence, we can draw conclusions on how far the topic of refugees shapes children's life worlds and to which group of children this applies. At the same time, the data gained from the survey tell us in how far children living in our country perceive refugee children as being in any way 'different', which is a precondition for thinking about how adults can support engagements with other children across perceived differences. The results also show how children experience those 'other' childhoods that do not correspond to the 'normative pattern' of a long and protected childhood (Bühler-Niederberger, 2011), which is so dominant in western industrialized nations and exported globally in the sense of a so to speak 'westernization of childhood'.

All this enables our study to open up a further perspective on the topic of 'multiple' (Neumann, 2011) and 'unequal childhoods' (Betz, 2008) discussed so repeatedly in German and international childhood studies. It does this in two ways: first, by focusing on experiences with a specific group of children in Germany that has previously not been subjected to systematic research in childhood studies; and second, by doing this from the perspective of those children who come into contact with the situation of refugees in their daily lives - without being refugees themselves. If we want to embed the refugee phenomenon and all its different facets within a theory of childhood, we need to view refugees in terms of the diversity and inequality of childhoods, also consider these children as actors, and focus on the interactions between refugee children and children who already live in Germany. Against this background this could further encourage us to regard the particular vulnerability of refugee children consequently as a social phenomenon, not only reflected in personal factors and individual biographies but also determined by structural and contextual conditions in the countries of arrival. Moreover, we could also talk about a type of childhood studies that sets another accent in the much-vaunted talk about the 'perspective of 
the child' (see Spyrou, 2011): It does not ask children to talk about themselves, but asks children to talk about children in order to shift from adult-centred perceptions of socio-politically relevant phenomena to how children view and support each other, not least in order to offer to refugee children a place in a society where they newly arrive. This as well sheds an insightful light on a special dimension of children's agency in society, which should be further explored in childhood studies.

Funding Open Access funding enabled and organized by Projekt DEAL.

Open Access This article is licensed under a Creative Commons Attribution 4.0 International License, which permits use, sharing, adaptation, distribution and reproduction in any medium or format, as long as you give appropriate credit to the original author(s) and the source, provide a link to the Creative Commons licence, and indicate if changes were made. The images or other third party material in this article are included in the article's Creative Commons licence, unless indicated otherwise in a credit line to the material. If material is not included in the article's Creative Commons licence and your intended use is not permitted by statutory regulation or exceeds the permitted use, you will need to obtain permission directly from the copyright holder. To view a copy of this licence, visit http://creativecommons.org/licen ses/by/4.0/.

\section{References}

Andresen, S., Çınar, D. \& Kuhn, M. (2018). Die qualitative Studie: 12 Portraits von Kinderpersönlichkeiten. In World Vision e.V. (Ed.), Kinder in Deutschland 2018. 4. World Vision Kinderstudie (pp. 229-328). Weinheim, Basel: Beltz.

Andresen, S., Fegter, S., Hurrelmann, K., \& Schneekloth, U. (Eds.). (2017). Well-being, poverty and justice from a child's perspective. 3rd World Vision Children Study. Children's well-being: Indicators and research No. 17. Springer International Publishing.

Andresen, S., \& Gerarts, K. (2016). Kindheitsforschung und ihre Zugangsmöglichkeiten zu geflüchteten Kindern. In J. Fischer, \& G. Graßhoff (Eds.), Unbegleitete minderjährige Flüchtlinge. „In erster Linie Kinder und Jugendliche! “. Sozialmagazin, Sonderband 1 (pp. 154-163). Weinheim: Beltz Juventa.

Andresen, S., \& Neumann, S. (2018). Die 4. World Vision Kinderstudie: Konzeptionelle Rahmung und thematischer Überblick. In World Vision e.V. (Ed.), Kinder in Deutschland 2018. 4. World Vision Kinderstudie (pp. 35-53). Weinheim, Basel: Beltz.

Andresen, S., \& Schneekloth, U. (2014). Wohlbefinden und Gerechtigkeit. Konzeptionelle Perspektiven und empirische Befunde der Kindheitsforschung am Beispiel der World Vision Kinderstudie 2013. Zeitschrift Für Pädagogik, 60(4), 535-551.

Andresen, S., \& Wilmes, J. (2016). Kinder einbeziehen: Teilhabe und Gerechtigkeit in der Kindheitsforschung. In L. Hartwig, G. Mennen, \& C. Schrapper (Eds.): Kinderrechte als Fixstern moderner Pädagogik? Grundlagen, Praxis, Perspektiven (pp. 35-53). Weinheim: Beltz Juventa.

Bartz, A. (2018). Schule und Flüchtlinge - Handlungs- und Spannungsfelder. In L. Hartwig, G. Mennen, \& C. Schrapper (Eds.), Handbuch Soziale Arbeit mit geflüchteten Kindern und Familien (pp. 515527). Beltz Juventa.

Ben-Arieh, A. (2008). The child indicators movement: Past, present, and future. Child Indicators Research, 1, 3-16. https://doi.org/10.1007/s12187-007-9003-1

Bergnehr, D., Aronson, O., \& Enell, S. (2020). Friends through school and family: Refugee girls' talk about friendship formation. Childhood, 27(4), 530-544. https://doi.org/10.1177/0907568220923718

Berry, J. W., Phinney, J. S., Sam, D. L., \& Vedder, P. (2006). Immigrant youth: acculturation, identity, and adaptation. Applied Psychology, 55(3), 303-332.

Betz, T. (2008). Ungleiche Kindheiten. Theoretische und empirische Analysen zur Sozialberichterstattung über Kinder. Juventa.

Bronfenbrenner, U. (1989). Ecological systems theory. Annals of Child Development, 6, 187-249.

Brumlik, M. (1992). Advokatorische Ethik. Zur Legitimation pädagogischer Eingriffe. KT-Verlag. 
Bühler-Niederberger, D. (2011). Lebensphase Kindheit. Theoretische Ansätze, Akteure und Handlungsräume. Weinheim, München: Juventa.

Bundesamt für Migration und Flüchtlinge (BAMF). (2017a): Aktuelle Zahlen zu Asyl. Tabellen, Diagramme, Erläuterungen. Ausgabe: Dezember 2016. http://www.bamf.de/SharedDocs/AnlagenDE/ Downloads/Infothek/StatistiAsyl/aktuelle-zahlen-zu-asyl-dezber-2016.html?nn=7952222. Accessed 12 June 2017.

Bundesamt für Migration und Flüchtlinge (BAMF). (2017b). Erstverteilung der Asylsuchenden (EASY). https://www.bamf.de/DE/Themen/AsylFluechtlingsschutz/AblaufAsylverfahrens/Erstverteilung/ erstverteilung-node.html Accessed 20 July 2017.

Calic, M.-J. (2005). Der erste, neue Krieg'. Staatszerfall und Radikalisierung der Gewalt im ehemaligen Jugoslawien. Zeitschrift Für Interkulturellen Fremdsprachenunterricht, 10(1), 71-87.

Colombo, E. (2010). Crossing differences: How young children of immigrants keep everyday multiculturalism alive. Journal of Intercultural Studies. https://doi.org/10.1080/07256868.2010.513081

Corsaro, W. A., Molinari, L., Gold Hadley, K., \& Sugioka, H. (2003). Keeping and making friends: Italian children's transition from preschool to elementary school. Social Psychology Quarterly, 66(3), 272-292.

Danby, S., Thompson, C., Theobald, M., \& Thorpe, K. (2012). Children's strategies for making friends when starting school. Australasian Journal of Early Childhood, 37(2), 63-71.

Demir, S. B., \& Ozgul, V. (2019). Syrian refugees minors in Turkey. Why and how are they discriminated against and ostracized? Child Indicators Research, 12, 1989-2011. https://doi.org/10.1007/ s12187-019-9622-3

Dryden-Peterson, S. (2016). Refugee education: The crossroads of globalization. Educational Researcher, 45(9), 473-482.

Eisenhuth, F. (2015). Strukturelle Diskriminierung von Kindern mit unsicheren Aufenthaltsstatus Subjekte der Gerechtigkeit zwischen Fremd- und Selbstpositionierungen. Springer.

Fattore, T. (2016). Children's conceptions of otherness: Constructions of the 'moral self' and implications for experiences of migration. In C. Hunner-Kreisel, \& S. Bohne (Eds.), Childhood, youth and migration. Connecting global and local perspectives (pp. 49-62). Dordrecht: Springer.

Fehr, E., Bernhard, H., \& Rockenbach, B. (2008). Egalitarianism in young children. Nature, 454, 1079-1083.

Fingerle, M., \& Wink, R. (Eds.). (2020). Forced migration and resilience. Conceptual issues and empirical results. Springer.

Frevert, U. (2013). Vergängliche Gefühle. Göttingen: Wallstein.

Gallacher, L. A., \& Gallagher, M. (2008). Methodological immaturity in childhood research? Thinking through 'participatory methods'. Childhood, 15(4), 499-516. https://doi.org/10.1177/0907568208091672

Geis, W., \& Orth, A.K. (2016). Flüchtlinge regional besser verteilen. Ausgangslage und Ansatzpunkte für einen neuen Verteilungsmechanismus, Gutachten für die Robert Bosch Stiftung. https://www. bosch-stiftung.de/sites/default/files/publications/pdf_import/IW_Gutachten_Regionale_Verteilung_ von_Fluechtlingen.pdf. Accessed 20 April 2020.

Genesis Online (2015). Datenportal des Statistischen Bundesamtes. http://www.genesis.destatis.de/ genesis/online/data;jsessionid=BF9024FBBD86F73DBD7E38C4FB43A63A.tomcat_GO_1_3? Menu=Willkommen. Accessed 14 December 2015.

Groundwater-Smith, S., Dockett, S., \& Bottrell, D. (2015). Participatory research with children and young people. Sage.

Gumbrecht, T. (2018). Unbegleitete minderjährige Flüchtlinge. In L. Hartwig, G. Mennen, \& C. Schrapper (Eds.), Handbuch Soziale Arbeit mit geflüchteten Kindern und Familien (pp. 209-212). Beltz Juventa.

Hall, S. (1990). Cultural identity and diaspora. In J. Rutherford (Ed.), Identity: community, culture, difference (pp. 222-237). Lawrence \& Wishart.

Hardman, C. (1973). Can there be an anthropology of childhood? Journal of the Anthropological Society of Oxford, 4(1), 85-99.

Hartwig, L., Mennen, G., \& Schrapper, C. (Eds.). (2018). Handbuch Soziale Arbeit mit geflüchteten Kindern und Familien. Beltz Juventa.

Honig, M.-S. (2009): Das Kind der Kindheitsforschung. Gegenstandskonstitution in den Childhood Studies. In Honig, M.-S. (Ed.),Ordnungen der Kindheit.Problemstellungen und Perspektiven der Kindheitsforschung(pp. 25-51).Weinheim, München: Juventa.

Honig, M.-S., Lange, A., \& Leu, H.R. (1999). Eigenart und Fremdheit. Kindheitsforschung und das Problem der Differenz von Kindern und Erwachsenen. In M.-S. Honig, A. Lange, \& H.R. Leu (Eds.), Aus der Perspektive von Kindern? Zur Methodologie der Kindheitsforschung (pp. 9-32). Weinheim, München: Juventa. 
Ismail, I. (2018). Bildung: Keine Integration ohne (informelle) Bildung. In L. Hartwig, G. Mennen, \& C. Schrapper (Eds.), Handbuch Soziale Arbeit mit geflüchteten Kindern und Familien (pp. 478-491). Beltz Juventa.

James, A. (1998). 'Foreword'. In I. Hutchby, \& J. Moran-Ellis (Eds.), Children and social competence: Arenas of action (pp. VII-X). London: Falmer Press.

James, A. (2007). Giving voice to children's voices. Practices and problems, pitfalls and potentials. American Anthropologist, 109(2), 261-272. https://doi.org/10.1525/aa.2007.109.2.261

Kämpfe, K., \& Westphal, M. (2016). Acquiring agency: Children's perspective within the context of migration in Germany. In C. Hunner-Kreisel, \& S. Bohne (Eds.), Childhood, youth and migration. Connecting global and local perspectives (pp. 63-80). Dordrecht: Springer.

Kirchner, M., Andresen, S., \& Schierbaum, K. (2017). Janusz Korczaks "schöpferisches Nichtwissen" vom Kind. Beiträge zur Kindheitsforschung. Springer VS.

Kruse, H. (2017). The SES-specific neighbourhood effect on interethnic friendship formation. The case of adolescent immigrants in Germany. European Sociological Review, 33(2), 182-194. https://doi. org/10.1093/esr/jcw056

Maaz, K., \& Jäger-Bieler, J. (2016). Integration durch Schule Die temporär notwendigen Behelfslösungen für Flüchtlingskinder sind nicht geeignet, um Bildungsungleichheiten dauerhaft entgegenzuwirken. DJI-Impulse, 3(2016), 22-25.

Maegusuku-Hewett, T., Dunkerley, D., Scourfield, J., \& Smalley, N. (2007). Refugee children in Wales: coping and adaptation in the face of adversity. Children \& Society, 21(4), 309-321. https://doi.org/ 10.1111/j.1099-0860.2007.00102.x

Magyar-Haas, Veronika (2017). Ausgesetzter Körper, verletzbarer Leib. Zur Regulierbarkeit von Emotionen. Zeitschrift für Soziologie der Erziehung und Sozialisation, 37(1 ), 39-54.

Meiner-Teubner, C. (2016). Flüchtlingskinder in der Warteschleife. Trotz großer Anstrengungen aller Akteure ist der Zugang zu Kinder tageseinrichtungen für geflüchtete Kinder erschwert. DJI-Impulse, $3 / 2016,19-22$

Lawrence, J. A., Kaplan, I., \& Collard, A. H. (2018). Perspectives of refugee children resettling in Australia on indicators of their well-being. Child Indicators Research, 12, 943-962. https://doi.org/10. 1007/s12187-018-9568-x

Luthar, S. S. (2015). Resilience in development: A synthesis of research across five decades. In D. Cichetti, \& D. J. Cohen (Eds.), Developmental Psychopathology, Vol. 3: Risk, Disorder, and Adaptation (pp. 739-795). 2nd edition. Hoboken: Wiley.

Nakeyar, C., Esses, V., \& Reid, G. J. (2017). The psychosocial needs of refugee children and youth and best practices for filling these needs: A systematic review. Clinical Child Psychology and Psychiatry, 23(2), 186-208.

Neumann, S. (2011). Was ist Kindheit(-sforschung) und wie viele gibt es? Tagungsbericht. Zeitschrift für Soziologie der Erziehung und Sozialisation, 31(4), 440-442.

Newland, L. A., Lawler, M. J., Giger, J. T., Roh, S., \& Carr, E. R. (2015). Predictors of Children's Subjective Well-Being in Rural Communities of the United States. Child Indicators Research, 8, 177-198. https://doi.org/10.1007/s12187-014-9287-x

Peucker, C., \& Seckinger, M. (2014). Flüchtlingskinder: eine vergessene Zielgruppe der Kinder- und Jugendhilfe. DJI Impulse, 1(2014), 12-14.

Prout, A. \& James, A. (1997). A new paradigm for the sociology of childhood? Provenance, promise and problems. In A. James \& A. Prout (Eds.), Constructing and reconstructing childhood. Comtemporary issues in the sociological study of childhood, 2nd edition (pp. 7-32). London: Falmer.

Pupeter, M., Wolfert, S., \& Schneekloth, U. (2018). Die Methodik der 4. World Vision Kinderstudie. In World Vision e.V. (Ed.), Kinder in Deutschland 2018. 4. World Vision Kinderstudie (pp. 345-351). Weinheim, Basel: Beltz.

Riedel, B., \& Lüders, K. (2016). Flüchtlingskinder in der Kita - Zugänge gestalten, Kooperation stützen! Kinder- und Jugendschutz in Wissenschaft und Praxis, 61(4), 138-142.

Rösch, T., Schneider, Weber, J., \& Worbs, S. (2020). Integration von Geflüchteten in ländlichen Räumen. Forschungsbericht 36. Nürnberg: Bundesamt für Migration und Flüchtlinge.

Schneekloth, U., Andresen, S., \& Neumann, S. (2018). Kinder und Geflüchtete: Wahrnehmung, Einstellungen und Begegnungen. In World Vision e.V. (Ed.), Kinder in Deutschland 2018. 4. World Vision Kinderstudie (pp. 196-228). Weinheim, Basel: Beltz.

Shallow, N. (2014). The wellbeing of refugee children in an early childhood education context: Connections and dilemmas. Journal of Educational Enquiry, 13(1), 18-34. 
Sirin, S. R. (2018). Increasing understanding for Syrian refugee children with empirical evidence. Vulnerable Children and Youth Studies, 13(1), 1-6.

Statistisches Bundesamt (Destatis). (2017a). Bevölkerung und Erwerbstätigkeit, Haushalte und Familien - Ergebnisse des Mikrozensus 2016. Fachserie 1 Reihe 3. Wiesbaden.

Statistisches Bundesamt (Destatis). (2017b). Bevölkerung und Erwerbstätigkeit, Bevölkerung mit Migrationshintergrund - Ergebnisse des Mikrozensus 2015. Fachserie 1 Reihe 2.2. Wiesbaden.

Spyrou, S. (2011). The limits of children's voices From authenticity to critical, reflexive representation. Childhood, 18(2), 151-165.

Sullivan, A. L., \& Simonsen, G. R. (2016). Systematic review of school-based social-emotional interventions for refugee and war-traumatized youth. Review of Educational Research. https://doi.org/10. 3102/0034654315609419

Thommessen, S., \& Todd, B. (2018). How do refugee children experience their new situation in England and Denmark? Implications for educational policy and practice. Children and Youth Services Review, 85, 228-238. https://doi.org/10.1016/j.childyouth.2017.12.025

Tobin, J. (2019). Addressing the needs of children of immigrants and refugee families in contemporary ECEC settings: Findings and implications from the Children Crossing Borders study. European Early Childhood Education Research Journal. https://doi.org/10.1080/1350293X.2020.1707359

UNHCR. (2019). Global Trends. Forced Displacement in 2019. https://www.unhcr.org/globaltren ds2019/. Accessed 30 October 2020.

UNICEF. (2020). Worlds of influence: Understanding what shapes child well-being in rich countries. Innocenti Report Card 16. Florence: UNICEF Office of Research - Innocenti.

de Wal Pastoor, L. (2016). Rethinking refugee education: Principles, policies and practice from a European perspective. Annual Review of Comparative and International Education. https://doi.org/10. 1108/S1479-367920160000030009

Watters, C. (2014). Well-being of asylum-seeking and refugee children. In A. Ben-Arieh, F. Casas, I. Frønes, \& J.E. Korbin (Eds.), Handbook of Child Well-being. Theories, methods and policies in global perspectives, Vol. 5 (pp. 3143-3158). Dordrecht: Springer.

Wünsche M., \& Fischer, S. (2020). Community Resilience. Networks for developing successful migration. In M. Fingerle, \& R. Wink (Eds.), Forced migration and resilience. Conceptual issues and empirical results. Wiesbaden: Springer, 45-69.

World Vision e.V. (Ed.). (2007). Kinder in Deutschland 2007. 1. World Vision Survey. Fischer Taschenbuch Verlag.

World Vision e.V. (Ed.). (2010). Kinder in Deutschland 2010. 2. World Vision Survey. Fischer Taschenbuch Verlag.

World Vision e.V. (Ed.). (2013). Wie gerecht ist unsere Welt? Kinder in Deutschland 2013. 3. World Vision Kinderstudie. Weinheim, Basel: Beltz.

World Vision e.V. (Ed.). (2018). Kinder in Deutschland 2018. 4. World Vision Kinderstudie . Weinheim, Basel: Beltz

Publisher's Note Springer Nature remains neutral with regard to jurisdictional claims in published maps and institutional affiliations. 